\title{
The Mediating Role of Customer Engagement on Brand Involvement and Emotional Brand Attachment
}

\author{
Shehla Qaiser*, Muhammad Adnan Bashir**, Muhammad \\ Yasir $^{* * *}$, and Syed Muhammad Fahim ${ }^{* * * *}$
}

\begin{abstract}
Online customer brand engagement (OCBE) has become an important relationship marketing construct within the realm of academics, as well as with practitioners. The emanating literature on OCBE offers diverse definitions, but those that are often presented without a mutual agreement. The extant literature based on this particular discipline primarily focused on the aspect of relationship marketing, with respect to retaining customers. But with the addition of customer engagement, it was not only confined towards maintaining customer retention, but also ventured into the subject of attracting new customers. This paper aims to validate a nomological set of theoretical relationships that include OCBE, brand involvement (BI), and emotional brand engagement (EBA). It provides a new outcome, EBA that has also been suggested in the previous studies. Also, it is noteworthy that this study has undertaken before brand usage intent that is used as a valid outcome. This study is exploratory in nature, and is limited to a base of customers who are engaged with a brand, by simply liking it on Facebook. In this regard, a survey of 302 respondents provided data, by resorting to purposive sampling between the age groups of $18-55$ years. Brand involvement is an antecedent of $O C B E$, and emotional brand attachment (EBA) was the outcome that was achieved. A further validation of this outcome was done through the mediation analysis, which concluded that only the affective dimension of OCBE had a mediating effect on the EBA. The affective dimension of OCBE has the most effect on the outcome variable EBA, as compared to the cognitive processing and activation dimensions of OCBE. This study concluded that marketers could perhaps devise social media strategies, in order to engage customers through emotions, and as a result help increase customer retention and loyalty.
\end{abstract}

Keywords: Brand involvement, emotional brand attachment, online customer brand engagement, consumer behavior.

\section{JEL Classification: M30, M31, M39}

\footnotetext{
* MPhil Scholar, Institute of Business Management, Karachi, Pakistan.

** Assistant Professor, Institute of Business Management, Karachi, Pakistan.

**** PhD Scholar, Institute of Business Management, Karachi, Pakistan.

${ }^{* * * *}$ Assistant Professor, Institute of Business Management, Karachi, Pakistan.
} 


\section{Introduction}

In the past two decades, the role of relationship marketing has been to devise strategies that can be used to retain customers. However, with the advent of engagement, the role of relationship marketing has significantly increased, by not only satisfying loyal customers, but by also engaging them beyond their decision to make a purchase. In addition to this, the role of relationship marketing also includes focusing on potential customers, and devising strategies to attract new customers, and effectively connecting with them (Vivek, Beatty, \& Morgan, 2012). Over time, as the markets and consumer behavior evolved, the goal of marketers transformed from nurturing relationship marketing, to engaging customers, by understanding that brand loyalty alone is not enough to retain customers (Kumar et al., 2010). Moreover, the literature developed in psychology advocated that engaged partners tend to have a strong emotional attachment, and enjoy more satisfying relationships (Kitayama, Markus, \& Kurokawa, 2000). In this regard, when all the aspects and activities of engagement are not taken into consideration, customers can mistakenly be overvalued, or undervalued (Kumar et al., 2010). This does not only result in miscalculating returns on the marketing activities, but can also lead to improper resource allocation, which ultimately affects the firm's equity and value (Rust, Ambler, Carpenter, Kumar, \& Srivastava, 2004; Verhoef et al., 2009).

The aim of relationship marketing has been to build long-lasting relationships with the customers (Berry \& Parasuraman, 2004). Social media enables customers to create stories that are related to brands, and the brand image, by helping them share and exchange information about their favorite brands (Gensler, Völckner, Liu-Thompkins, \& Wiertz, 2013). Marketers are now concentrating on building good relationships with customers that go beyond purchases, and the customers in return feel more connected to the people and organizations behind these brands that they frequently use (Kumar et al., 2010). Due to this positive relationship building, customers are continuously providing information to marketing firms, and this process is becoming increasingly interactive. This essentially helps in building long-term bonds between the customers and the firms, adding elements of engagement to effective relationship marketing (Vivek et al., 2012). As a result, customers have now become more participative, perceptive, powerful, and want to actively engage with brands, who co-direct the way they are perceiving marketing activities. Following the same context, the topic of online customer brand engagement has captivated immense interest among the experts who 
study other related disciplines, such as information systems, psychology, education, management, and marketing. As a consequence, this has provoked and triggered a new wave of understanding when it comes to customer-brand interaction (Hollebeek, 2011). Marketers also realize the immense potential in these developments, and believe that an online engagement strategy can effectively aid in providing a strategic advantage, and give the firms the capability to be more lucrative than their competitors (Gorgus, 2016). In light of these developments, there is a persistent need to understand the drivers and outcomes of OCBE, in order to develop strategies for effective and positive relationship marketing.

The challenges of the Digital era have given birth to a new term, OCBE, which primarily represents the customers' interactions with the various brands that they come in contact with (Edelman, 2007). There has been an ever-growing interest in the active engagement and attention given to the customer, by marketers, so as to become more lucrative in the interactions that are made through social media. However, there is a paucity of literature in this particular field of marketing. It is noteworthy that, in relationship marketing there exists a gap in terms of the active management of online engagement with brands, and there is also a dire need to understand the process of engagement from an academic point of view (Gorgus, 2016).

Online customers who are engaged by the brand, show enhanced levels of loyalty, trust, commitment, satisfaction, and emotional bonding towards the focal brand in consideration (Brodie, Ilic, Juric, \& Hollebeek, 2013). Engagement has often been studied in the Pakistani context, in different fields of research. Some of these fields are often related to human resource management, with a focus on employee engagement (Ahmed \& Ansari, 2020), while other studies are based on customer engagement in terms of gender and brand relationships (Bashir \& Ali, 2016). In this regard, researchers have recommended various predictors and outcomes of engagement, and have also suggested that there is a need to corroborate these proposed variables with quantitative methods, in order to test the scale of engagement in different situations (Mollen \& Wilson, 2010). The construct of engagement is beneficial in determining which segment to cater to, while at the same time, devising marketing strategies and creating engaging Facebook content (Gummerus, Liljander, Weman, \& Pihlström, 2012). The OCBE is proposed in order to highlight the cognitive, emotional and behavioral contributions that come into play, especially when interacting with a specific brand. Therefore, this concept is in mutual understanding with the social exchange theory (Hollebeek, Glynn, \& Brodie , 2014) . OCBE 
is the customer's spontaneous contribution towards the focal brand, which goes beyond the purchase decision (Pansari \& Kumar, 2017). In this regard, a 10-item scale was validated by (Hollebeek et al., 2014), in order to measure the three-dimensional OCBE measurement scale In broad terms, there are various predictors of engagement, as it is an iterative process that ideally takes time to take its complete course (Bowden, 2008). However, it is uncertain whether OCBE is mostly behavioral in nature (Van Doorn et al., 2010), or has any additional cognitive and emotional facets to its key features (Harrigan et al., 2018). Moreover, the conceptual network of OCBE is also evolving continuously, and is mostly presented in theoretical terms (Hollebeek et al., 2014; Vivek et al., 2012), by exploring the key relationships that have managerial implications attached to them. The Marketing Science Institute (MSI) recommends that OCBE should ideally be the focal preference of research in the coming years. The emphasis should be laid upon the definition and measurement scales, and also on how social media can aid in devising strategies to enhance engagement behaviors (Rizley, 2014). In this context, the antecedents and consequences of customer engagement have become critical factors that need to be decoded, so that marketers can devise effective and appropriate strategies, accordingly (Pansari \& Kumar, 2017).

When a Facebook user likes a brand's page, and follows it, in order to get frequent updates of the products that are being offered, a phenomenon that can be termed as online brand engagement (Wallace, Buil, Chernatony, De, \& Buil, 2014) comes into play. Also, engagement is inclusive, and incorporates every individual who is connecting with the Facebook brand page, by purchasing, or not purchasing, the brand (Gorgus 2016). Therefore, it can be assumed that the platform, Facebook, has become a major marketing platform for brands to delve into positive engagement, by creating brand awareness. Brands, by the number of likes, shares, or comments they get on Facebook, show that consumers who tend to like, share or comment on a Facebook page are considered to be more engaged with a particular brand (Malhotra \& Dash, 2010). Thus, keeping these intricacies in mind, the objective of this study is to determine the mediating effect of OCBE, on BI and EBA. All the users of Facebook pages, who have liked at least one favorite clothing brand, are either male or female, between the age group of 18 and above, and residing in Karachi, constitute towards the sample population for this research. A proposed conceptual model of OCBE is offered, and includes BI as an antecedent, and EBA as the outcome. 


\section{Theoretical Background and Hypotheses Development}

\subsection{Brand Involvement and $O C B E$}

It is evident from the extant literature that brand involvement is a predominant driver of OCBE. It manifests the needs and values of customers' interest in a particular brand, by processing the intellectual information that is available for this purpose (De Vries \& Carlson, 2014). The term engagement refers to a condition where individuals are fully involved, occupied, or captivated by a brand, giving it the liberty of their uninterrupted attention (Higgins, 2009). Customers can nurture a high or low level of emotional, or informational involvement towards their preferred social media. Highly engaged customers tend to gather more information about their preferred brands, and can also acquire extensive knowledge of competitive brands, before making their purchase decisions (Bowden, 2008). However, customers who have a lower level of engagement with the brands, make use of secondary clues and ponder deeper into the actual knowledge available regarding a particular brand of interest (Gordon, McKeage, \& Fox, 1998). According to the Interdependence Theory, being actively interactive and engaged towards any brand is a more rewarding experience for customers (Van Lange \& Balliet, 2015). This theory emphasizes on maintaining communication and interaction between the customers and the focal brand, as well as creating long-lasting relationships that go beyond the purchase decisions (Van Lange \& Balliet, 2015). Involvement here is not only taken to be behavioral, but is also considered to be a cognitive, affective, or motivational driver (Zaichkowsky, 1985). In formal terms, engagement comprises of three interactive dimensions; cognitive, affective, and behavioral (Harrigan et al., 2018). At the cognitive level, BI leads to online engagement. This then results in brand-related thought processing, and is linked to how much a customer speculates about a particular brand. At the affective level, customers with a positive online experience can view a brand as being fascinating. Lastly, at the activation level of engagement, estimations about the amount of time that would be spent switching from one social media site to another, by the customer, are made (Hollebeek et al., 2014).

Keeping these factors in mind, the following hypotheses have been formulated:

$\mathbf{H}_{1 \mathrm{a}}$ : $\mathrm{BI}$ has a positive link with the cognitive processing dimension of OCBE 
$\mathbf{H}_{1 \mathrm{~b}}$ : $\mathrm{BI}$ has a positive relationship with the affective dimension of OCBE $\mathbf{H}_{1 \mathbf{c}}$ : BI has a positive associations with the activation dimension of OCBE.

\subsection{OCBE and Emotional Brand Attachment}

According to research studies, emotions tend to play a pivotal role in determining consumer behavior and purchase decisions (Gaur, Herjanto, \& Makkar, 2014; Holbrook, 1995). When customers become emotionally attached to a brand, they perceive it to be an extension of their self, and consider it to be meaningful and significant in their lives (Park, Macinnis, \& Priester, 2006). Lichtenberg (2001), the attachment theorist, suggested that human behavior is guided by a set of five motivational systems. Out of these motivational systems, the attachment-affiliation system, and the exploration-assertion system are of particular relevance to this study. The attachment system stimulates closeness and care-seeking behaviors, whereas the exploration system stimulates engagement with the surroundings. Periodic repetition of this engagement behavior results in the molding of the behavior, and any related emotional states that might be experienced. Eventually, there is an emergence of an unconscious psychological structure (an internal working model of the relationship), which reveals the factors of conscious awareness, as a long-term, specific affective bond that is extended towards the attachment figure (Morgan, 2010). A customer can be easily satisfied after consuming a particular brand, but the emotional attachment develops after numerous interactions with it. In this regard, EBA connects a customer to a focal brand that portrays feelings of passion, affection, and connection (Thomson, Macinnis, \& Park, 2005). In contextual terms, affection refers to a feeling of amiability, peace, and affection of the customers, towards a focal brand. In addition to this, a connection refers to a feeling of attachment towards a focal brand, while passion refers to a feeling of customer engagement and satisfaction, with a focal brand (Thomson et al., 2005). It is common for customers to become emotionally attached to material possessions, such as brands (Schultz \& Baker, 2004). Emotions tend to positively or negatively influence our decisions, and connect or disconnect customers towards the brands that they interact with. In this manner, an emotional connection, albeit negative, between a brand, and its customer is gradually formed (Malär, Krohmer, Hoyer, \& Nyffenegger, 2011). The attachment theory advocates that the degree of emotional attachment that is linked to a brand, anticipates the nature of the individual's interaction with that brand (Bowlby \& Ainsworth, 2013). Although this theory targets human relationships, earlier research has demonstrated that consumers can 
nurture a relationship with brands, just like they do with humans (Aaker, 1997). A customer's emotional connection to a focal brand can anticipate feelings of engagement and devotion towards a particular brand (Thomson et al., 2005). This is the outcome of engagement between brands and customers, that the customers experience on social media (Phillips \& Baumgartner, 2002), that is created through relationship marketing. Therefore, the dependent outcome variable in this study is the EBA, that is derived from the attachment theory (Bowlby \& Ainsworth, 2013). Thus, the hypotheses developed in this regard propose that;

$\mathbf{H}_{\mathbf{2 a}}$ : The cognitive processing dimension of OCBE has a significant effect on EBA.

$\mathbf{H}_{\mathbf{2 b}}$ : The affective dimension of OCBE has a significant effect on EBA.

$\mathbf{H}_{2 \mathbf{c}}$ : The activation dimension of OCBE has a significant effect on EBA.

\subsection{Mediated Effects}

Significant relational outcomes, such as greater commitment, confidence, emotional brand attachment, and loyalty can also be the possible consequences of OCBE (Brodie et al., 2013). In order to create OCBE, that is not only transient, but can also lead to an emotional and prolonged relationship between two parties, if handled competently, the interactive dealings of shoppers and retailers on social networking sites have been deduced. It is likely that sales will also increase based on this phase of enhanced consumer involvement. This is primarily because engaged customers are not only pleased or committed, but are also explicitly linked to the brand of their choice. Therefore, the participation of customers on social networking sites is primarily supported by an emotional attachment (Toor, Husnain, \& Hussain, 2017).

For further validation of the model, the mediation analysis hypotheses propose that;

$\mathbf{H}_{3 \mathbf{a}}$ : The cognitive processing dimension of OCBE mediates the effect of brand involvement on emotional brand attachment.

$\mathbf{H}_{3 \mathrm{~b}}$ : The affective dimension of OCBE mediates the effect of brand involvement on emotional brand attachment.

$\mathbf{H}_{3 \mathbf{c}}$ : The activation dimension of OCBE mediates the effect of brand involvement on emotional brand attachment. 
The relationships among the study constructs as proposed in the above-mentioned hypotheses are depicted in the following Figure 1.

Figure 1: Conceptual Model

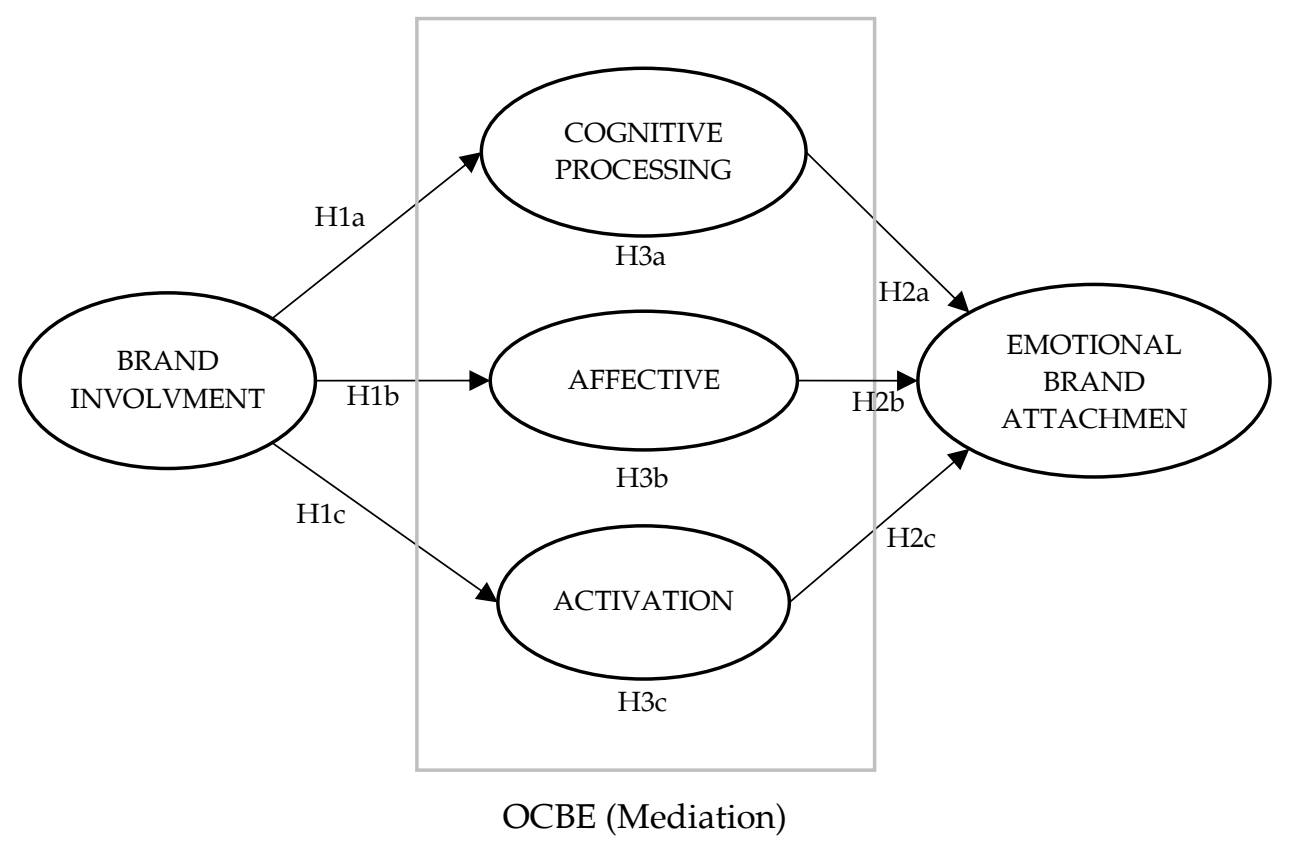

\section{Research Methodology}

\subsection{Data collection}

For the purpose of this study, the primary data was collected through a questionnaire that was circulated in person, and through the internet. Additionally, this questionnaire was adopted by using the existing validated instruments. The literature review suggests that Facebook is currently the best social media tool that can be utilized to create positive online brand engagement. The respondents of this study were informed about the voluntary nature of their participation, and were also ensured of complete anonymity. There were two screening questions for the respondents, before qualifying for the survey. The first screening question was whether they have liked any Facebook pages, and the second was whether they have a favorite clothing brand that they have liked on Facebook, and are following that brand for frequent updates. The total number of respondents were 320 , but after a preliminary screening of the data, 18 questionnaires were deemed redundant due to non-engaging responses. The antecedents in this model were identified to be brand 
involvement, the three mediators that represent the dimensions of OCBE, and the outcome variable, that is the emotional brand attachment. The constructs of the study were measured using the multi-item, 5-point Likert Scales, with a scale of 5 representing a response of strongly agreed, and 1 representing strongly disagreed. Moreover, the BI scale has been adapted from (De Vries \& Carlson, 2014), and contains six items $(\alpha=0.91)$. The EBA scale has been adapted from (Levy \& Hino, 2016), and also contains six items $(\alpha=0.92)$. The OCBE scale has been adapted from (Hollebeek et al., 2014 ), and contains three-dimensional constructs, that further contain ten items $(\alpha=0.93)$. In addition to this, for the model fit and hypotheses, the structural equation model (SEM) in IBM AMOS 21, and for the mediation analysis PROCESS 3.3 (Hayes, 2012) software were undertaken.

Table 1: Demographic Profile

\begin{tabular}{lcc}
\hline Demographics & No. & (\%) (Approximately) \\
\hline Gender & 143 & 47.4 \\
Male & 159 & 52.6 \\
Female & & \\
Age & 112 & 37.1 \\
$18-25$ & 84 & 27.8 \\
$26-35$ & 60 & 19.9 \\
$36-45$ & 26 & 8.6 \\
$46-55$ & 20 & 6.6 \\
$>55$ & & \\
Employment status & 150 & 49.7 \\
Employed & 83 & 27.5 \\
Unemployed & 69 & 22.8 \\
Self-employed & & \\
Monthly income & 140 & 46.4 \\
$<50 \mathrm{k}$ & 76 & 25.2 \\
50k-100k & 36 & 11.9 \\
100k-200k & 50 & 16.6 \\
>200k & & \\
\hline
\end{tabular}

The age of the respondents that were considered was 18 years and above, since our target audience were Facebook users who have liked the page of at least one of their favorite clothing brands. The demographic profile in table 1 shows that 143 respondents were male, comprising of $47 \%$ of the total respondents, and 159 respondents were female, comprising of $53 \%$ of the total respondents that were considered for the purpose of this research. The age limit of the respondents that ranged from 18 to 25 was $112(37 \%), 26$ to 35 was $84(28 \%), 36$ to 45 was $60(20 \%), 46$ to 55 was $26(9 \%)$ 
and lastly, more than 55 was $20(7 \%)$. Most of the respondents who were active users of Facebook were between the ages of 18 to 35. The employment status of the respondents showed that 150 of them were employed (50\%), $83(28 \%)$ were unemployed and were mostly students, and 69 were self-employed (23\%). Lastly, when considering the monthly income of the respondents, those that earned more than 50k were 140 in number $(47 \%)$, those that earned between $50 \mathrm{k}$ and $100 \mathrm{k}$ were $76(25 \%)$, those that earned between 100k and 200k were $36(12 \%)$, and those that earned more than $200 \mathrm{k}$ were $50(17 \%)$ in number.

\subsection{Data Analysis}

The Structural Equation Modeling (SEM) approach was followed. Initially, the measurement model of the scales was tested using the exploratory and confirmatory techniques, so as to assess reliability, dimensionality, and validity. Secondly, the structural model was evaluated by testing the hypotheses via performing the regression analysis, and the mediation analysis was done using the IBM Amos 21, and the PROCESS 3.3, respectively.

Table 2: Exploratory Factor Analysis (EFA)

\begin{tabular}{lcccc}
\hline Constructs & $\begin{array}{c}\text { Kaiser- } \\
\text { Meyer-Olkin } \\
\text { Measure of } \\
\text { Sampling } \\
\text { Adequacy }\end{array}$ & $\begin{array}{c}\text { Bartlett's } \\
\text { Test of } \\
\text { Sphericity }\end{array}$ & $\begin{array}{c}\text { Total } \\
\text { Variance } \\
\text { Explained }\end{array}$ & $\begin{array}{c}\text { Items } \\
\text { retained }\end{array}$ \\
\hline BI & 0.853 & 793.153 & 78.72 & 4 \\
EBA & 0.746 & 497.87 & 81.38 & 3 \\
OCBE & 0.840 & 1187.73 & 67.58 & 6 \\
\hline
\end{tabular}

Table 2 shows that the EFA and three factors emerged as expected. While from the BI construct, 4 out of the 6 items were retained. Moving on, for EBA, out of the 6 items, 3 were retained due to the cross loading, and in OCBE, there were a total of 10 items, but 6 were retained due to crossloading. The extraction method used for this purpose was the Principal Component Analysis (PCA), and the Promax Rotation, with Kaiser Normalization was carried out on all the three constructs. The values of the Barley Test of Sphericity came out to be significant, with a p-value that was less than 0.05. A total of 302 respondents were included in the survey, and the values of Kaiser-Meyer-Olkin (KMO) for all the latent variables were well above the acceptable range (KMO > 0.6) (Hair, Black, Babin, \& Anderson, 2014). 


\subsection{Measurement Model Results}

Table 3: Discriminant Validity Index Summary

\begin{tabular}{lccc}
\hline Constructs & $\begin{array}{c}\text { Brand } \\
\text { Involvement }\end{array}$ & $\begin{array}{c}\text { Emotional } \\
\text { Brand } \\
\text { Attachment }\end{array}$ & $\begin{array}{c}\text { Online Customer } \\
\text { Brand } \\
\text { Engagement }\end{array}$ \\
\hline $\begin{array}{l}\text { Brand Involvement } \\
\text { Emotional Brand }\end{array}$ & $\mathbf{0 . 8 4 7}$ & $\mathbf{0 . 8 4 8}$ & \\
$\begin{array}{l}\text { Attachment } \\
\text { Online Customer }\end{array}$ & 0.824 & 0.848 & $\mathbf{0 . 8 7 2}$ \\
Brand Engagement & 0.728 & 0 & \\
\hline
\end{tabular}

The results presented in Table 3 suggest that all the latent variables in the research model indicate towards a discriminant validity. This is because the square root of the total variance explained is greater than the square of each pair of correlation (Fornell \& Larcker, 1981), and the correlation values among them are lesser than 0.85 (Mohamad, Mohammad, Azman, \& Ali, 2016). The descriptive statistics along with correlation table and collinearity diagnostics are provided in the Appendix. 
Table 4: Factor Loading, Composite Reliability, and Average Variance Extracted

\begin{tabular}{|c|c|c|c|}
\hline Constructs & Loading & CR & AVE \\
\hline $\begin{array}{l}\text { Brand Involvement (De Vries \& Carlson } \\
\text { 2014) }\end{array}$ & & 0.910 & 0.717 \\
\hline $\begin{array}{l}\text { My favorite clothing brand means a lot to me } \\
\text { (B2) }\end{array}$ & 0.83 & & \\
\hline $\begin{array}{l}\text { I consider my favorite clothing brand a } \\
\text { relevant part of my life (B3) }\end{array}$ & 0.83 & & \\
\hline $\begin{array}{l}\text { For me, personally, my favorite clothing } \\
\text { brand is important (B4) }\end{array}$ & 0.84 & & \\
\hline It is a meaningful clothing brand for me (B5) & 0.88 & & \\
\hline $\begin{array}{l}\text { Emotional brand attachment (Thomson et al. } \\
\text { 2005) }\end{array}$ & & 0.885 & 0.720 \\
\hline $\begin{array}{l}\text { I identify with what my favorite clothing } \\
\text { brand stands for (E2) }\end{array}$ & 0.84 & & \\
\hline $\begin{array}{l}\text { I feel a sense of belonging regarding my } \\
\text { favorite clothing brand (E3) }\end{array}$ & 0.84 & & \\
\hline $\begin{array}{l}\text { I am highly regarded by my favorite clothing } \\
\text { brand (E5) }\end{array}$ & 0.87 & & \\
\hline $\begin{array}{l}\text { Online customer brand engagement } \\
\text { (Hollebeek et al. 2014) } \\
\text { Cognitive }\end{array}$ & & 0.904 & 0.761 \\
\hline $\begin{array}{l}\text { When I see my favorite clothing brands social } \\
\text { media activities, I start to think about it (C1) }\end{array}$ & 0.83 & & \\
\hline $\begin{array}{l}\text { While I am interacting with my favorite } \\
\text { clothing brand, I think a lot about it (C2) }\end{array}$ & 0.85 & & \\
\hline Affective & & & \\
\hline $\begin{array}{l}\text { Following my favorite clothing brands, the } \\
\text { Facebook account makes me happy (AFF2) }\end{array}$ & 0.87 & & \\
\hline $\begin{array}{l}\text { I feel good when I am interacting with my } \\
\text { favorite clothing brand (AFF3) }\end{array}$ & 0.91 & & \\
\hline Activation & & & \\
\hline $\begin{array}{l}\text { Whenever I am online on Facebook, I usually } \\
\text { look for my favorite clothing brand (AC2) }\end{array}$ & 0.90 & & \\
\hline $\begin{array}{l}\text { I generally interact with my favorite clothing } \\
\text { brand when I log on to Facebook (AC3) }\end{array}$ & 0.85 & & \\
\hline
\end{tabular}

Table 4 shows the factor loading, AVE, and CR, which show an adequate factor of convergent reliability and validity ( $C R \geq 0.7, \mathrm{AVE} \geq 0.5)$ of the measurement model (Hair et al., 2014). In addition to this, the factor loading values of all the items measuring brand involvement, emotional brand attachment, and online customer brand engagement, are higher than 0.6. Moreover, the Confirmatory Factor Analysis (CFA) was undertaken by 
using all the three latent variables with the 13 items that were included in one single multifactorial CFA model, in AMOS 21. Thus, the CFA measurement model indicates an adequate model fit: $\chi 2(59)=172.4 ; \chi 2 / \mathrm{df}$ $=2.923 ; \mathrm{GFI}=.924 ; \mathrm{CFI}=.963 ; \mathrm{RMSEA}=.080 ;$ and $\mathrm{SRMR}=.062$.

\subsection{Structural Model Results}

Table 5: Structural Model Results for Total and Direct Effects

\begin{tabular}{lcccc}
\hline Hypothesized relationships & $\boldsymbol{\beta}$ & $\mathbf{t}$ & $\mathbf{p}$ & Decision \\
\hline $\begin{array}{l}\mathbf{H}_{1 \mathrm{a}} \text { : Brand involvement has a } \\
\text { significant effect on the cognitive } \\
\text { processing dimension of OCBE }\end{array}$ & .6415 & 12.96 & $<0.05$ & Supported \\
$\begin{array}{l}\mathbf{H}_{1 \mathrm{~b}}: \text { Brand involvement has a } \\
\text { significant effect on the affective }\end{array}$ & .3217 & 6.55 & $<0.05$ & Supported \\
$\begin{array}{l}\text { dimension of OCBE } \\
\mathbf{H}_{1 \mathrm{c}} \text { : Brand involvement has a } \\
\text { significant effect on the }\end{array}$ & .0942 & 1.528 & $>0.05$ & Not Supported \\
$\begin{array}{l}\text { activation dimension of OCBE } \\
\mathbf{H}_{2 \mathrm{a}:} \text { The cognitive processing } \\
\text { dimension of OCBE has a } \\
\text { significant effect on emotional } \\
\text { brand attachment }\end{array}$ & .1100 & 2.201 & $>0.05$ & Not Supported \\
$\begin{array}{l}\mathbf{H}_{2 \mathrm{~b}} \text { : The affective dimension of } \\
\text { OCBE has a significant effect on } \\
\text { emotional brand attachment }\end{array}$ & .3090 & 5.396 & $<0.05$ & Supported \\
$\begin{array}{l}\mathbf{H}_{2 \mathrm{c}} \text { The activation dimension of } \\
\text { OCBE has a significant effect on } \\
\text { emotional brand attachment }\end{array}$ & .0724 & 1.649 & $>0.05$ & Not Supported \\
\hline
\end{tabular}

Table 5 depicts that (path a), which is BI, has a significant effect on the cognitive processing and affective dimensions of OCBE, and has no effect on the activation dimension. Therefore, it can be confirmed that hypotheses $\mathbf{H}_{1 \mathrm{a}}$ and $\mathbf{H}_{1 \mathrm{~b}}$ are supported, while $\mathbf{H}_{1 \mathrm{c}}$ is not supported. Whereas the cognitive processing dimension of OCBE has a greater effect on BI, as compared to the affective dimension of OCBE. The results (path b) depict that the cognitive processing, and activation dimension of OCBE are not significant, but the affection dimension of OCBE has a significant effect on the dependent outcome variable, EBA. From the results, it is therefore concluded that $\mathbf{H}_{2 a}$ and $\mathbf{H}_{2 c}$ are not supported, and only $\mathbf{H}_{2 b}$ is supported. Furthermore, the mediation analysis was conducted for the structural model, in order for the exploration of the multiple OCBE mediators, concurrently between $\mathrm{BI}$ and the dependent outcome variable EBA (Hayes, 2009). 
Table 6: Structural Model Results for Indirect Effects

\begin{tabular}{lcccc}
\hline $\begin{array}{l}\text { Indirect Effect For } \\
\text { Mediation Analysis }\end{array}$ & $\boldsymbol{\beta}$ & LLCI & ULCI & Decision \\
\hline $\begin{array}{l}\mathbf{H}_{3 \mathrm{a}} \text { Cognitive processing } \\
\text { dimension of OCBE } \\
\text { significantly mediates the }\end{array}$ & 0.706 & -0.009 & 0.150 & $\begin{array}{c}\text { Not } \\
\text { Supported }\end{array}$ \\
effect of brand \\
$\begin{array}{l}\text { involvement on emotional } \\
\text { brand attachment }\end{array}$ & & & & \\
$\begin{array}{l}\mathbf{H}_{3 \mathrm{~b}} \text { : Affective dimension } \\
\text { of OCBE significantly } \\
\text { mediates the effect of } \\
\text { brand involvement on }\end{array}$ & 0.099 & 0.050 & 0.157 & Supported \\
emotional brand & & & & \\
attachment & & & & \\
$\begin{array}{l}\mathbf{H}_{3 c} \text { : Activation dimension } \\
\text { of OCBE significantly } \\
\text { mediates the effect of } \\
\text { brand involvement on } \\
\text { emotional brand } \\
\text { attachment }\end{array}$ & -0.006 & -0.022 & 0.003 & $\begin{array}{c}\text { Not } \\
\text { Supported }\end{array}$ \\
\hline
\end{tabular}

Table 6 indicates the indirect effects of BI on EBA, with the OCBE mediators pertaining to cognitive processing, affective, and activation. The results (path c) show a significant indirect effect of BI on EBA, with the three OCBE mediators: $\beta=0.471$; $\mathrm{SE}=0.046 ; 95 \% \mathrm{CI}=.3789$ to $.5634(\mathrm{p}=$ $0.00)$. Since the C.I. does not include zero, it is concluded that there is a mediating effect between BI and EBA (Hayes, 2012). It is also concluded that there (path $\mathrm{c}$ ) is a significant direct effect of BI, on EBA: $\beta=0.776$; $(p$ $=0.001$ ), suggesting partial mediation (Hayes, 2012). The results from Table 6 conclude that for the mediation analysis, $\mathrm{BI}$ is mediated through only one of the OCBE dimensions that is an affective dimension to EBA, thus supporting $\mathbf{H}_{3 \mathrm{~b}}$. The $\mathbf{H}_{3 \mathrm{a}}$ and $\mathbf{H}_{3 \mathrm{c}}$ are not supported, since both the dimensions, cognitive processing, and activation of the C.I. include a zero, therefore, there is no mediation observed in this case.

\section{Discussion}

This study focuses on a much comprehensive interpretation of OCBE, and is not limited to customer purchases exclusively. Certain quantitative methods were applied in this study, as suggested by various researchers who were found in the emerging literature, in order to get a grasp on the concept of engagement (Gorgus, 2016). In the context of 
clothing brands, this study concludes that the affective dimension of OCBE has a significant influence on EBA. Moreover, BI has a significant effect on both the cognitive processing and affective dimensions of OCBE, especially when compared to the research findings of (Hollebeek et al., 2014; Loureiro, Gorgus, \& Kaufmann, 2017), where BI happened to have a positive impact on all the three dimensions. Furthermore, greater involvement with tourism websites reveals that greater levels of all the three dimensions of $\mathrm{CBE}$ with $\mathrm{BI}$, positively associate with all the three dimensions of OCBE. These findings are similar to the earlier studies that have been advocating that customers that are highly involved are likely to be emotionally attached and connected with their favorite focal brands as well (Bowden, 2008). These findings also resonate with studies that have been conducted on the tourism industry, where consumers who are involved, and have indulged in cognitive and affective investments, are more engaged with the brand, and can accumulate added benefits (Harrigan et al., 2018). The cognitive and emotional element of OCBE integrates experiences and the feelings of customers, without focusing on the actual purchase intention (Vivek et al., 2012). Therefore, this study concludes that brand involvement is influenced by the cognitive and affective dimensions of OCBE, and not on the behavioral dimension that refers to activation in this case. Furthermore, through the mediation analysis, it is revealed that only the affective dimension of OCBE has a significant effect on EBA. This study can help marketers to devise strategies to keep their customers engaged, by connecting with them to the brand emotionally. Additionally, the marketers can devise social media campaigns that customers can relate to themselves, and that can have a long-lasting imprint through the positive reinforcement of emotions. For example, brands can increase the interaction of engaged customers, by expressing their emotions through virtual platforms. This can be undertaken by sharing messages, pictures, and videos. Marketers can also make the content more fascinating, which would engage the customers every time they visit their Facebook page. Whether it is relationship marketing or services marketing, it is evident that OCBE can have a profound impact on the customers by engaging them emotionally, and creating a long-lasting imprint in the hearts and minds of its customers (Dwivedi, Johnson, Wilkie, \& De Araujo-Gil, 2018). In this regard, marketers need to create exciting and mind-blowing content that would ultimately make the customers come back for more, and then indulge in transactional and word of mouth behavior. The concept of engagement targets potential customers, as well as repeat customers, so the marketers 
can devise different strategies for these two segments of customers, in order to convert them into loyal and dedicated customers (Bowden, 2009).

\section{Limitations and Recommendations}

The sample size that is considered for this study could have been larger, but due to time restraints it was not possible. Moreover, this study is restricted to Karachi only, and in the next phase, it can be carried out in other cities of Pakistan as well. Other than this, a cross-sectional survey can be conducted to further validate the results, and the OCBE scale can be further validated and tested. An area for future research would be to capture the pre and post visit levels of engagement, using a longitudinal research design. In this regard, the S-D logic can be used as a theory, so as to better understand the OCBE drivers and outcomes. Additionally, more drivers and outcomes can also be studied to fully understand the engagement dimensions. Also, this research is limited to apparel brands, while other product types can also be taken into consideration. A comparative study of the hedonic and utilitarian brands can be studied as well. Also, this study can also be conducted using other social media tools like Instagram, Twitter, and Snapchat, to name a few. Furthermore, a comparative analysis of millennials' customers and elderly customers can be done. 


\section{References}

Aaker, J. L. (1997). Dimensions of brand personality. Journal of Marketing Research, 34(4), 347-356

Ahmed, S., \& Ansari, J. (2020). What leads to Employee Engagement in Pharmaceutical Sector of Pakistan? Journal of Management and Research, 7(1), 161-183. doi: https://doi.org/10.29145//jmr/ $71 / 070107$

Bashir, A., \& Ali, N. A. (2016). Impact of Customer Brand Relationship through Facebook on the Level of Customer Engagement. Pakistan Business Review, 18(1), 159-178.

Berry, L. L., \& Parasuraman, A. (2004). Marketing Services: Competing Through Quality. New York, USA; Simon and Schuster.

Bowden, J. L.-H. (2008). The process of customer engagement: A conceptual framework. Journal of Marketing Theory and Practice, 17(1), 63-74. doi: https://doi.org/10.2753/mtp1069-6679170105

Bowden, J. L.-H. (2009). The process of customer engagement: A conceptual framework. Journal of Marketing Theory and Practice, 17(1), 63-74. doi: https:/ /doi.org/10.2753/MTP1069-6679170105

Bowlby, J., \& Ainsworth, M. (2013). The origins of attachment theory. Attachment theory: Social, developmental, and clinical perspectives, 45 , 759-775.

Brodie, R. J., Ilic, A., Juric, B., \& Hollebeek, L. (2013). Consumer engagement in a virtual brand community: An exploratory analysis. Journal of Business Research, 66(1), 105-114.

De Vries, N. J., \& Carlson, J. (2014). Examining the drivers and brand performance implications of customer engagement with brands in the social media environment. Journal of Brand Management, 21(6), 495-515. doi: https://doi.org/10.1057/bm.2014.18

Dwivedi, A., Johnson, L. W., Wilkie, D. C., \& De Araujo-Gil, L. (2018). Consumer emotional brand attachment with social media brands and social media brand equity. European Journal of Marketing, 53(6), 1176-1204. EJM-09-2016-0511. doi: https://doi.org/10.1108/EJM09-2016-0511 
Edelman, D. C. (2007). From the periphery to the core: As online strategy becomes overall strategy; marketing organizations and agencies will never be the same. Journal of Advertising Research, 47(2), 130134. doi: https:/ / doi.org/10.2501/S0021849907070146

Fornell, C., \& Larcker, D. F. (1981). Evaluating structural equation models with unobservable variables and measurement error. Journal of marketing research, 18(1), 39-50.

Gaur, S. S., Herjanto, H., \& Makkar, M. (2014). Review of emotions research in marketing, 2002-2013. Journal of Retailing and Consumer Services, 21(6), 917-923.

Gensler, S., Völckner, F., Liu-Thompkins, Y., \& Wiertz, C. (2013). Managing brands in the social media environment. Journal of Interactive Marketing, 27(4), 242-256. doi: https://doi.org/10.1016/ j.intmar.2013.09.004

Gordon, M. E., McKeage, K., \& Fox, M. A. (1998). Relationship marketing effectiveness: the role of involvement. Psychology $\mathcal{E}$ Marketing, 15(5), 443-459.

Gorgus, T. M. C. (2016). Online brand engagement: an investigation on antecedents and outcomes within the social media environment (Masters dissertation). Instituto Universitario de Lisboa, Portugal.

Gummerus, J., Liljander, V., Weman, E., \& Pihlström, M. (2012). Customer engagement in a Facebook brand community. Management Research Review, $35 \quad$ (9),857-877. doi: https://doi.org/10.1108/ 01409171211256578

Hair, J. F., Black, W. C., Babin, B. J., \& Anderson, R. E. (2014). Multivariate data analysis: Pearson new international edition. Essex, England: Pearson Education Limited.

Harrigan, P., Evers, U., Miles, M. P., \& Daly, T. (2018). Customer engagement and the relationship between involvement, engagement, self-brand connection and brand usage intent. Journal of Business Research, 88(November), 388-396. doi: https://doi.org/10.1016/j.jbusres.2017.11.046 
Hayes, A. F. (2009). Beyond Baron and Kenny: Statistical Mediation Analysis in the New Millennium. Communication Monographs, 76(4), 408-420. doi: https://doi.org/10.1080/03637750903310360

Hayes, A. F. (2012). Process: A versatile computational tool for observed variable mediation, moderation, and conditional process modeling. [White paper]. Retrieved from http://www.afhayes.com/ public/process2012.pdf

Higgins, T. \& Scholer. A. (2009). Engaging the Consumer: The Science and Art of the Value Creation Process. Journal of Consumer Psychology, 19(2), 100-114.

Holbrook, M. B. (1995). Consumer Research: Introspective Essays on the Study of Consumption, London, UK: Sage

Hollebeek, L. (2011). Exploring customer brand engagement: Definition and themes. Journal of Strategic Marketing, 19(7), 555-573. doi: https://doi.org/10.1080/0965254X.2011.599493

Hollebeek, L. D., Glynn, M. S., \& Brodie, R. J. (2014). Consumer brand engagement in social media: Conceptualization, scale development and validation. Journal of Interactive Marketing, 28(2), 149-165. https://doi.org/10.1016/j.intmar.2013.12.002

Kitayama, S., \& Markus, H. R. Kurokawa, (2000). Culture, emotion, and well-being: Good feelings in Japan and the United States. Cognition and Emotion, 14(1), 93-124.

Kumar, V., Aksoy, L., Donkers, B., Venkatesan, R., Wiesel, T., \& Tillmanns, S. (2010). Undervalued or overvalued customers: Capturing total customer engagement value. Journal of Service Research, 13(3), 297310. doi: https:/ / doi.org/10.1177/1094670510375602

Lichtenberg, J. D. (2001). Motivational systems and model scenes with special references to bodily experience. Psychoanalytic Inquiry, 21(3), 430-447.

Levy, S., \& Hino, H. (2016). Emotional brand attachment: A factor in customer-bank relationships. International Journal of Bank Marketing, 34(2), 136-150. doi: https:/ / doi.org/10.1108/IJBM-06-2015-0092 
Loureiro, S. M. C., Gorgus, T., \& Kaufmann, H. R. (2017). Antecedents and outcomes of online brand engagement: The role of brand love on enhancing electronic-word-of-mouth. Online Information Review, 41(7), 985-1005. doi: https:/ / doi.org/10.1108/OIR-08-2016-0236

Malär, L., Krohmer, H., Hoyer, W. D., \& Nyffenegger, B. (2011). Emotional Brand Attachment and Brand Personality: The Relative Importance of the Actual and the Ideal Self. Journal of Marketing, 75(4), 35-52. doi: https://doi.org/10.1509/jmkg.75.4.35

Malhotra, N. K., \& Dash, S. (2010). Marketing research: An applied orientation. New Delhi, India: Pearson Education

Mohamad, M., Mohammad, M., Azman, N., \& Ali, M. (2016). The impact of life satisfaction on substance abuse: Delinquency as a mediator. International Journal of Adolescence and Youth, 3843(March 2017), 111. doi: https://doi.org/10.1080/02673843.2016.1267021

Mollen, A., \& Wilson, H. (2010). Engagement, telepresence and interactivity in online consumer experience: Reconciling scholastic and managerial perspectives. Journal of Business Research, 63(9-10), 919-925. doi: https://doi.org/10.1016/j.jbusres.2009.05.014

Morgan, P. (2010). Towards a developmental theory of place attachment. Journal of Environmental Psychology, 30(1), 11-22. doi: https://doi.org/10.1016/j.jenvp.2009.07.001

Pansari, A., \& Kumar, V. (2017). Customer engagement: The construct, antecedents, and consequences. Journal of the Academy of Marketing Science, 45(3), 294-311. doi: https://doi.org/10.1007/s11747-0160485-6

Park, C. W., Macinnis, D. J., \& Priester, J. (2006). Beyond Attitudes: Attachment and Consumer Behavior, 12(2), 3-35.

Phillips, D. M., \& Baumgartner, H. (2002). The role of consumption emotions in the satisfaction response. Journal of Consumer psychology, 12(3), 243-252.

Rizley, R. L. (2014). 2014-2016 research priorities. Cambridge MA: Marketing Science Institute. Retrieved from http://www.msi.org/research/ 2014-2016-research-priorities / 
Rust, R. T., Ambler, T., Carpenter, G. S., Kumar, V., \& Srivastava, R. K. (2004). Measuring Marketing Productivity: Current Knowledge and Future Directions. Journal of Marketing, 68(4), 76-89. doi: https://doi.org/10.1509/jmkg.68.4.76.42721

Schultz, S., \& Baker, S. M. (2004). An Integrative Review of Material Possession Attachment. Academy of Marketing Science Review, 2004(1), 1-35.

Thomson, M., Macinnis, D. J., \& Park, C. W. (2005). Thomason et al. (2005). Journal of Consumer Psychology, 15(1), 77-91.

Toor, A., Husnain, M., \& Hussain, T. (2017). The Impact of Social Network Marketing on Consumer Purchase Intention in Pakistan: Consumer Engagement as a Mediator,10 (1),167-199.

Van Doorn, J., Lemon, K. N., Mittal, V., Nass, S., Pick, D., Pirner, P., \& Verhoef, P. C. (2010). Customer engagement behavior: Theoretical foundations and research directions. Journal of Service Research, 13(3), 253-266. doi: https://doi.org/10.1177/1094670510375599

Van Lange, P. A. M., \& Balliet, D. (2015). Interdependence theory. APA Handbook of Personality and Social Psychology, 3, 65-92.

Verhoef, P. C., Lemon, K. N., Parasuraman, A., Roggeveen, A., Tsiros, M., \& Schlesinger, L. A. (2009). Customer Experience Creation: Determinants, Dynamics and Management Strategies. Journal of Retailing, 85(1), 31-41. doi: https://doi.org/10.1016/ j.jretai.2008.11.001

Vivek, S. D., Beatty, S. E., \& Morgan, R. M. (2012). Customer engagement: Exploring customer relationships beyond purchase. Journal of Marketing Theory and Practice, 20(2), 122-146. doi: https: / /doi.org/10.2753/mtp1069-6679200201

Wallace, E., Buil, I., Chernatony, L. De, \& Buil, I. (2014). Consumer engagement with self-expressive brands: Brand love and WOM outcomes. Journal of Product and Brand Management, 23(1), 33-42 doi: https: / /doi.org/10.1108/JPBM-06-2013-0326

Zaichkowsky, J. L. (1985). Measuring the involvement construct. Journal of consumer research, 12(3), 341-352. 


\section{Appendix}

Table-A: Descriptive Statistics and Reliability Analysis

\begin{tabular}{lccccc}
\hline & Mean & $\begin{array}{c}\text { Std. } \\
\text { Dev }\end{array}$ & Skewness & Kurtosis & $\begin{array}{c}\text { Cronbach's } \\
\text { Alpha }\end{array}$ \\
\hline $\begin{array}{l}\text { Brand } \\
\text { Involvement }\end{array}$ & 2.9073 & 1.08929 & .099 & -.770 & .910 \\
$\begin{array}{l}\text { Emotional Brand } \\
\text { Attachment }\end{array}$ & 2.7252 & 1.14082 & .057 & -1.026 & .886 \\
$\begin{array}{l}\text { Online Customer } \\
\text { Brand }\end{array}$ & 2.7715 & 1.01949 & -.139 & -.672 & .903 \\
Engagement & & & & & \\
\hline
\end{tabular}

Table-B: Correlation Results

\begin{tabular}{lccc}
\hline Constructs & BI & EBA & OCBE \\
\hline Brand Involvement & $\mathbf{1}$ & & \\
Emotional Brand Attachment & .741 & $\mathbf{1}$ & \\
$\begin{array}{l}\text { Online Customer Brand } \\
\text { Engagement }\end{array}$ & .617 & .719 & $\mathbf{1}$ \\
\hline
\end{tabular}

Table-C: Tolerance

\begin{tabular}{lc}
\hline Constructs & Tolerance \\
\hline Brand Involvement & .436 \\
Emotional Brand Attachment & .467 \\
Online Customer Brand Engagement & .340 \\
\hline
\end{tabular}

